\title{
Lactobacillus plantarum B7 attenuates Salmonella typhimurium infection in mice: preclinical study in vitro and in vivo
}

\author{
Siwaporn Wongsen', Duangporn Werawatganon ${ }^{1, *}$, Somying Tumwasorn ${ }^{2}$
}

\begin{abstract}
Background: Salmonella typhimurium is a cause of gastroenteritis including diarrhea. Lactobacillus plantarum is a probiotic widely used to prevent and treat diarrhea.

Objectives: To determine the protective effects of L. plantarum B7 on diarrhea in mice induced by S. typhimurium.

Methods: Inhibition of S. typhimurium growth by L. plantarum B7 was determined using an agar spot method. Mice were divided into 3 groups $\left(\mathrm{n}=8\right.$ each): a control group, an $\mathrm{S}$ group administered $3 \times 10^{9} \mathrm{CFU} / \mathrm{mL}$ S. typhimurium, and an $\mathrm{S}+\mathrm{LP}$ group administered $1 \times 10^{9} \mathrm{CFU} / \mathrm{mL}$ L. plantarum $\mathrm{B} 7$ and $3 \times 10^{9} \mathrm{CFU} / \mathrm{mL}$ S. typhimurium daily for 3 days. Counts of $S$. typhimurium and percentage of fecal moisture content (\%FMC) were determined from stool samples. Serum levels of tumor necrosis factor- $\alpha$ (TNF- $\alpha$ ), interleukin-6 (IL-6), and CXCL1 were determined.

Results: L. plantarum B7 produced a clear zone on S. typhimurium. There were significantly less S. typhimurium in the feces from mice in the S+LP group than in the S group. Serum levels of TNF- $\alpha$, IL-6, and CXCL1 in mice from the $S$ group were significantly higher than levels in the S+LP and control groups. Feces from mice in the S group were soft and loose, whereas in the S+LP group they were hard and rod shaped. The \%FMC in the S+LP group was significantly less than in the $\mathrm{S}$ group.

Conclusions: L. plantarum B7 can inhibit growth of S. typhimurium, decrease levels of proinflammatory cytokines, and attenuate symptoms of diarrhea induced in mice by $S$. typhimurium.
\end{abstract}

Keywords: bacteremia; diarrhea; gastroenteritis; Lactobacillus plantarum; Salmonella typhimurium

Salmonella typhimurium is an enteropathogen in the family Enterobacteriaceae, and a major cause of acute gastroenteritis and bacteremia [1]. In addition to diarrhea, common symptoms including nausea, vomiting, abdominal pain, fever, and weakness, appear 12-72 h after infection with S. typhimurium [2]. In most people, symptoms usually last 4-7 days and the infection does not require treatment. However, some patients the infection may progress with severe symptoms, which can be dangerous and life threatening. S. typhimurium can spread from intestines to the blood and eventually cause death without appropriate and timely antibiotic treatment [3]. Diarrhea induced by Salmonella is mostly treated with antibiotics and

*Correspondence to: Duangporn Werawatganon, Department of Physiology, Faculty of Medicine, Chulalongkorn University, Bangkok 10330, Thailand, e-mail: Duangporn.w@chula.ac.th

'Alternative and Complementary Medicine for Gastrointestinal and Liver Diseases Research Unit, Department of Physiology, Faculty of Medicine, Chulalongkorn University, Bangkok 10330, Thailand

${ }^{2}$ Department of Microbiology, Faculty of Medicine, Chulalongkorn University, Bangkok 10330, Thailand

¿ Open Access. ( 2018 Siwaporn Wongsen et al., published by Sciendo. (cc))BY-NC-ND This work is licensed under the Creative Commons Attribution NonCommercial-NoDerivatives 4.0 License. 
anti-inflammatory agents; however, the use of antibiotics and anti-inflammatory agents may have adverse effects and often leads to antibiotic resistance.

One alternative treatment for diarrhea induced by Salmonella is the use of probiotics. Probiotics are natural, live microorganisms; when administered in adequate amounts, they can promote health benefits for the host [4, 5]. Many strains of probiotics (e.g., Lactobacillus rhamnosus GG, Lactobacillus reuteri, Lactobacillus casei, Lactobacillus acidophilus CL1285, Escherichia coli strain Nissle 1917, bifidobacteria, enterococci [Enterococcus faecium SF68], and Saccharomyces boulardii) can inhibit growth, metabolic activity, and adhesion of pathogenic enteric bacteria (Salmonella, Shigella, E. coli, or Vibrio cholerae) to intestinal epithelial cells [6]. Potential mechanisms of probiotics to prevent and treat of diarrhea include protection of intestinal epithelial function and regulation and modifications of the intestinal microbial environment. Lactobacillus plantarum is a gram-positive bacterium in the Lactobacillaceae family. Normal flora are found in the human gastrointestinal (GI) tract and the reproductive system [7]. In the food industry, L. plantarum has fermentative properties and has benefits in food and beverage production including for yogurt, cheese, pickles, beer, wine, and cider. In medicine, L. plantarum is used mostly as a probiotic and biotherapeutic agent to prevent and treat GI disease and diarrhea [8-10]. Some strains of L. plantarum inhibit pathogen growth [11], prevent adhesion and invasion of enteropathogens to intestinal epithelial cells [12], act as an anti-inflammatory and regulate immunomodulatory activities to reduce inflammatory responses $[13,14]$, which enhances intestinal function to prevent diarrhea [15] and reduces allergenicity from soy flour [16].

The present study aims to determine the protective effects of L. plantarum B7 on diarrhea in mice associated with $S$. typhimurium and to illustrate the role of inflammatory response of $S$. typhimurium infection in mice.

\section{Materials and methods}

\section{Assay of inhibitory activity in vitro: preparation of bacteria}

S. typhimurium (Salmonella enterica serovar Typhimurium) ATCC 13311 were grown on tryptic soy agar (TSA) at $37^{\circ} \mathrm{C}$ in aerobic conditions for $24 \mathrm{~h}$ and adjusted to final concentration of $1 \times 10^{7} \mathrm{CFU} / \mathrm{mL}$. The frozen cultures of L. plantarum B7 were precultivated on de Man, Rogosa and Sharpe (MRS) agar at $37^{\circ} \mathrm{C}$ for $48 \mathrm{~h}$ in anaerobic conditions. Then, a single colony was isolated and subcultured on MRS broth 2 times in 96-well plates and incubated at $37^{\circ} \mathrm{C}$ for $48 \mathrm{~h}$ in anaerobic conditions. L. plantarum $\mathrm{B} 7$ was isolated and spotted into each well of a 96-well plate containing brain heart infusion (BHI) agar. Supplements with $20 \mathrm{mM}$ glucose in $140 \mathrm{~mm}$ plates were incubated at $37^{\circ} \mathrm{C}$ under anaerobic condition for $24-48 \mathrm{~h}$. Plates were then overlaid with $20 \mathrm{~mL}$ of TSA (7.5 g agar/L) and overnight culture of $S$. typhimurium at $1 \times 10^{7} \mathrm{CFU} / \mathrm{mL}$ and incubated at $37^{\circ} \mathrm{C}$ for $24 \mathrm{~h}$. In the present study, L. rhamnosus L34 was used as a positive control and $L$. fermentum L12 was used as a negative control.

\section{Agar spot method}

An agar spot method previously described by Spinler et al. [17] was used to determine antimicrobial activity of L. plantarum $\mathrm{B} 7$ against $S$. typhimurium.

\section{Study in mice}

\section{Bacterial preparation}

S. typhimurium ATCC 13311 were cultured on Salmonella Shigella agar (SS agar, Oxoid) by incubation at $37^{\circ} \mathrm{C}$ under aerobic conditions for $24 \mathrm{~h}$. The colonies of S. typhimurium ATCC 13311 were harvested and adjusted to a final concentration of $3 \times 10^{9} \mathrm{CFU} / \mathrm{mL}$ suspended in $0.85 \%$ saline.

L. plantarum B7 was previously isolated from a gastric biopsy of a dyspeptic patient and identified by sequence analysis of the amplified 16S rRNA gene product [18]. The L. plantarum $\mathrm{B} 7$ were maintained at $-80^{\circ} \mathrm{C}$ in MRS broth containing $20 \%$ glycerol at the Department of Microbiology, Faculty of Medicine, Chulalongkorn University.

The L. plantarum B7 were recovered from frozen stock and cultivated twice on MRS agar anaerobically $\left(10 \% \mathrm{CO}_{2}\right.$, $10 \% \mathrm{H}_{2}$, and $80 \% \mathrm{~N}_{2}$ ) in an anaerobic jar at $37^{\circ} \mathrm{C}$ for $48 \mathrm{~h}$. Colonies of $L$. plantarum $\mathrm{B} 7$ were harvested and adjusted to a final concentration of $1 \times 10^{8} \mathrm{CFU} / \mathrm{mL}$ suspended in $0.85 \%$ saline.

\section{Experimental design}

Male albino mice, weighing about 20-25 g, were purchased from the National Laboratory Animal Center, Salaya Campus, Mahidol University, Nakornpathom, Thailand. The animals were housed in a temperature-controlled room at $25 \pm 1^{\circ} \mathrm{C}$ 
under a 12:12 h light-dark cycle. All procedures conducted on animals were approved by the Animal Ethics Committee, Faculty of Medicine, Chulalongkorn University (approval No. 3/57) and conformed with the Institute of Laboratory Animal Resources, Commission on Life Sciences, National Research Council "Guide for the Care and Use of Laboratory Animals" Washington, D.C.: National Academy Press; 1996. Overall, 24 mice were separated without selection into 3 groups as follows:

- Group 1 (Control group, $\mathrm{n}=8$ ): mice administered with $0.85 \%$ saline $1 \mathrm{~mL}$ by oral gavage once a day for 3 days and housed with free access to water and standard food.

- Group 2 ( $\mathrm{S}$ group, $\mathrm{n}=8$ ): mice administered with $3 \times 10^{9} \mathrm{CFU}$ S. typhimurium $1 \mathrm{~mL}$ suspended in $0.85 \%$ saline by oral gavage once a day for 3 days and housed with free access to water and standard food.

- Group $3(\mathrm{~S}+$ LP group $\mathrm{n}=8$ ): mice administered with $1 \times 10^{8} \mathrm{CFU}$ L. plantarum B7 suspended $0.85 \%$ saline $1 \mathrm{~mL}$ by oral gavage. After treatment with $L$. plantarum B7 for $2 \mathrm{~h}$, mice were administered $3 \times 10^{9} \mathrm{CFU}$ S. typhimurium suspended in $0.85 \%$ saline $1 \mathrm{~mL}$ by oral gavage for 3 days and housed with free access to water and standard food.

Before administering $3 \times 10^{9} \mathrm{CFU}$ S. typhimurium or $1 \times 10^{8} \mathrm{CFU}$ L. plantarum $\mathrm{B} 7$, mice were pretreated with streptomycin suspended in drinking water $(5 \mathrm{mg} / \mathrm{mL})$ for 3 days as described by Barth et al. [19].

Mouse body weight, activities, and fecal characteristics were recorded daily. Fresh feces were collected to determine $S$. typhimurium infection by stool culture by colony counting and fecal moisture content was measured. All mice were humanely killed by an overdose of thiopental sodium injected intraperitoneally. Blood samples were collected by cardiac puncture to determine tumor necrosis factor- $\alpha$ (TNF- $\alpha$ ), interleukin (IL-6), and CXCL1 levels in serum using enzyme-linked immunosorbent assays (ELISAs).

\section{Determination of S. Typhimurium in feces: stool culture with colony count}

Fresh feces $(1 \mathrm{~g})$ were homogenized in $400 \mu \mathrm{L}$ phosphatebuffered saline at $\mathrm{pH} 7.4$ and prepared with serial dilution $10^{-1}-10^{-7}$. A $100 \mu \mathrm{L}$ suspension was spread on the SS agar plate that was then incubated at $37^{\circ} \mathrm{C}$ for $24 \mathrm{~h}$. The plates of S. typhimurium with colony counts yielding approximately 30-300 colonies were selected. To confirm that the selected colonies were $S$. typhimurium, a triple sugar iron (TSI) slant agar test was used. A single colony of S. typhimurium from an SS agar plate was inoculated onto TSI slant agar and incubated at $37^{\circ} \mathrm{C}$ for $24 \mathrm{~h}$. Appearance of TSI agar positive test result was confirmed by serological testing using Salmonella group B antibodies. The number of $S$. typhimurium in each sample was calculated as follows:

$$
\begin{gathered}
\text { Number of bacteria } / \mathrm{mL} \\
(\mathrm{CFU} / \mathrm{mL})
\end{gathered}=\frac{\begin{array}{l}
\text { Number of colonies on plate } \\
\times \text { reciprocal of dilution sample }
\end{array}}{\text { Volume of sample }}
$$

\section{Assay of fecal moisture content}

Moisture content of fecal samples was determined by the percentage of water left from fecal drying using a microwave oven. Fresh fecal samples (1 g) were collected, weighed, and recorded as "wet weight of sample." Wet samples were then dried at $101-105^{\circ} \mathrm{C}$ using a microwave oven. After they were allowed to cool, the samples were then weighed and recorded as "dry weight of sample" $[20,21]$. The moisture content of the samples was calculated with the following equation:

$$
\begin{aligned}
& A=\text { Weight of wet sample }(\text { grams }) \\
& B=\text { Weight of dry sample }(\text { grams }) \\
& \% \text { Fecal moisture content }=\frac{A-B}{B} \times 100
\end{aligned}
$$

\section{Assay of serum cytokine levels}

\section{Serum sample preparation}

Blood samples were collected via cardiac puncture and allowed to clot for $2 \mathrm{~h}$ at room temperature before centrifuging for $20 \mathrm{~min}$ at approximately $1000 \times \mathrm{g}$. The serum was removed and stored at $-80^{\circ} \mathrm{C}$ until determining TNF- $\alpha$, IL-6, and CXCL1 levels using ELISA kits (R\&D Systems).

\section{Statistical analyses}

We used PASW Statistics for Windows (version 18.0; SPSS Inc.) for statistical analyses. Continuous data are presented as mean \pm standard deviation (SD). Means between groups of animals were compared with a one-way analysis of variance followed by a Tukey post hoc test. Differences were considered statistically significant at $P<0.05$. 


\section{Results}

\section{Assay of inhibitory activity of L. plantarum B7 against}

\section{S. typhimurium in vitro}

The inhibitory effect of L. plantarum B7 against S. typhimurium is expressed as a clear zone $(\mathrm{C})$ and microcolonies $(\mathrm{M})$ on the lawn of $S$. typhimurium around the spot of L. plantarum B7. In the present study, L. fermentum L12 was used as a negative control and L. rhamnosus L34 was used as a positive control. $L$. plantarum B7 has a clear zone around the spot, which demonstrates inhibitory activity against $S$. typhimurium (Figure 1).

\section{Study of mice in vivo}

\section{Concentration of S. typhimurium in feces}

The mean concentration of $S$. typhimurium in feces from mice in the $\mathrm{S}+\mathrm{LP}$ group $(7.42 \pm 0.05 \log \mathrm{CFU} / \mathrm{g})$ was significantly less than the concentration in feces from mice in the $\mathrm{S}$ group $(8.86 \pm 0.02 \log \mathrm{CFU} / \mathrm{g} ;$ Figure 2$)$

\section{Serum level of TNF-}

Levels of TNF- $\alpha$ in serum of mice from the $\mathrm{S}$ group $(128.59 \pm 12.82 \mathrm{pg} / \mathrm{mL})$ were significantly greater than levels in mice from the control group $(53.49 \pm 8.90 \mathrm{pg} / \mathrm{mL})$ and mice from the S+LP group $(36.15 \pm 9.22 \mathrm{pg} / \mathrm{mL})$ (Figure 3).

\section{Serum level of IL-6}

IL-6 levels in serum of mice from the S group (144.44 \pm 8.91 $\mathrm{pg} / \mathrm{mL}$ ) were significantly greater than levels in serum from mice in the control group $(66.51 \pm 4.04 \mathrm{pg} / \mathrm{mL})$ and mice in the $\mathrm{S}+\mathrm{LP}$ group $(70.36 \pm 5.37 \mathrm{pg} / \mathrm{mL}$; Figure 4).

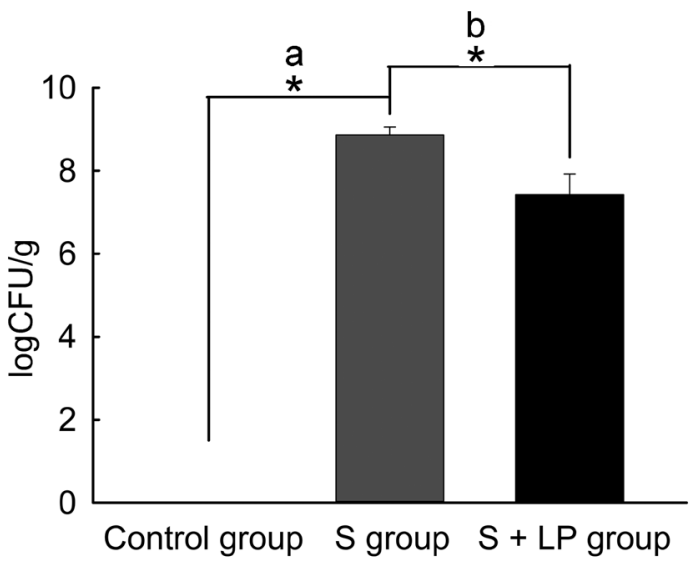

Figure 2. Concentration of $S$. typhimurium in $1 \mathrm{~g}$ feces (logCFU/g). Control group $(n=8)$ : mice administered $0.85 \%$ saline; $S$ group $(n=8)$ : mice administered S. typhimurium $3 \times 10^{9} \mathrm{CFU} / \mathrm{mL} ; \mathrm{S}+\mathrm{LP}$ group $(\mathrm{n}=8)$ : mice administered L. plantarum $\mathrm{B} 71 \times 10^{8} \mathrm{CFU} / \mathrm{mL}$ and S. typhimurium $3 \times 10^{9} \mathrm{CFU} / \mathrm{mL}$. ${ }^{*} P<0.05$

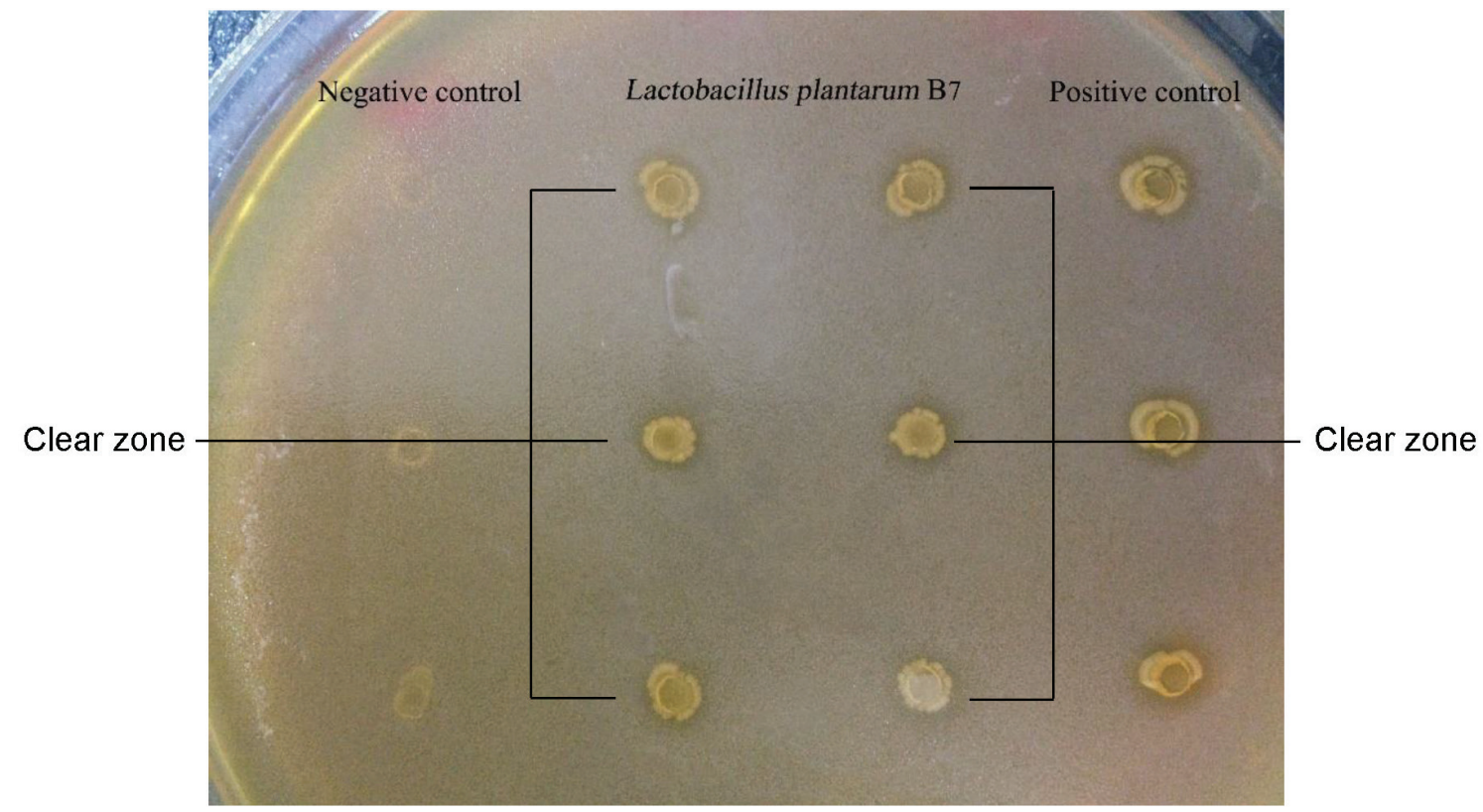

Figure 1. L. plantarum B7 spots grown on $20 \mathrm{mM}$ glucose $\mathrm{BH}$ lagar under anaerobic conditions at $37^{\circ} \mathrm{C}$, $48 \mathrm{~h}$, overlaid with $10^{7} \mathrm{~S}$. Typhimurium and incubated at $37^{\circ} \mathrm{C}, 24 \mathrm{~h}$, under aerobic conditions. Clear zone $(C)$ and microcolonies $(M)$ around the spot $(n=6)$. 


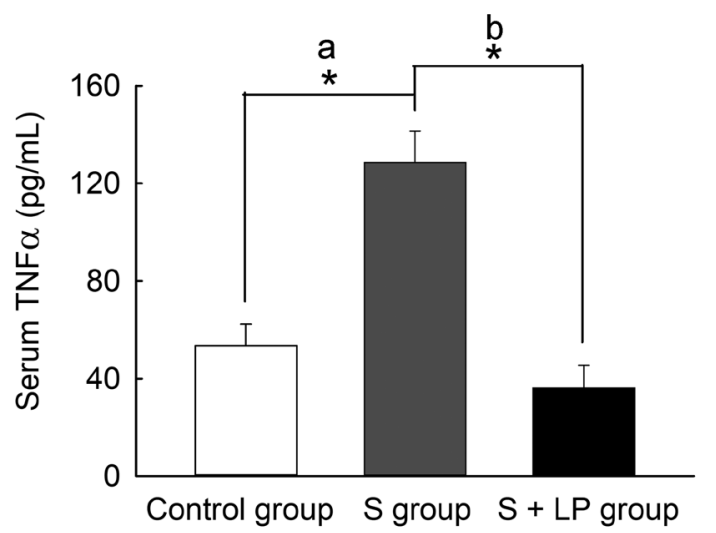

Figure 3. Concentration of serum TNF- $\alpha(\mathrm{pg} / \mathrm{mL})$. Control group $(\mathrm{n}=8)$ : mice administered $0.85 \%$ saline; $S$ group $(n=8)$ : mice administered S. typhimurium $3 \times 10^{9} \mathrm{CFU} / \mathrm{mL} ; \mathrm{S}+\mathrm{LP}$ group $(\mathrm{n}=8)$ : mice administered L. plantarum $\mathrm{B} 71 \times 10^{8} \mathrm{CFU} / \mathrm{mL}$ and S. typhimurium $3 \times 10^{9} \mathrm{CFU} / \mathrm{mL}$. ${ }^{*} P<0.05$

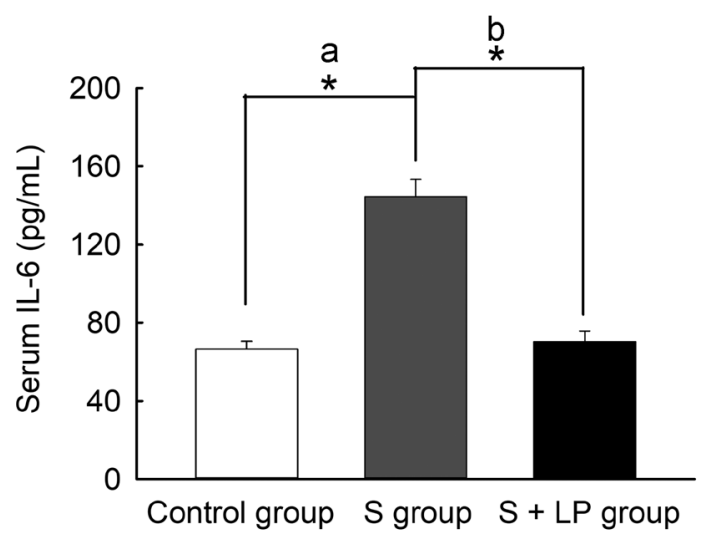

Figure 4. Concentration of serum IL-6 $(\mathrm{pg} / \mathrm{mL})$. Control group $(n=8)$ : mice administered with $0.85 \%$ saline; $S$ group $(n=8)$ : mice administered S. typhimurium $3 \times 10^{\circ} \mathrm{CFU} / \mathrm{mL} ; \mathrm{S}+\mathrm{LP}$ group $(\mathrm{n}=8)$ : mice administered L. plantarum $\mathrm{B} 71 \times 10^{8} \mathrm{CFU} / \mathrm{mL}$ and $S$. typhimurium $3 \times 10^{9} \mathrm{CFU} / \mathrm{mL} .{ }^{*} P<0.05$.

\section{Serum level of CXCL1}

CXCL1 levels in serum from mice in the $\mathrm{S}$ group $(96.09 \pm 10.81$ $\mathrm{pg} / \mathrm{mL}$ ) were significantly greater than levels in serum from mice in the control group $(32.32 \pm 4.54 \mathrm{pg} / \mathrm{mL})$ and mice in the $\mathrm{S}+\mathrm{LP}$ group $(35.40 \pm 2.77 \mathrm{pg} / \mathrm{mL}$; Figure 5).

\section{Fecal characteristics}

In the control group, feces were rod shaped, dark colored, and trifling with no sawdust around their surface. In the $\mathrm{S}$ group, after being fed with $S$. typhimurium feces were loose, soft, and lighter in color with sawdust covering their surface. Similar in appearance to feces from the control group, feces in the

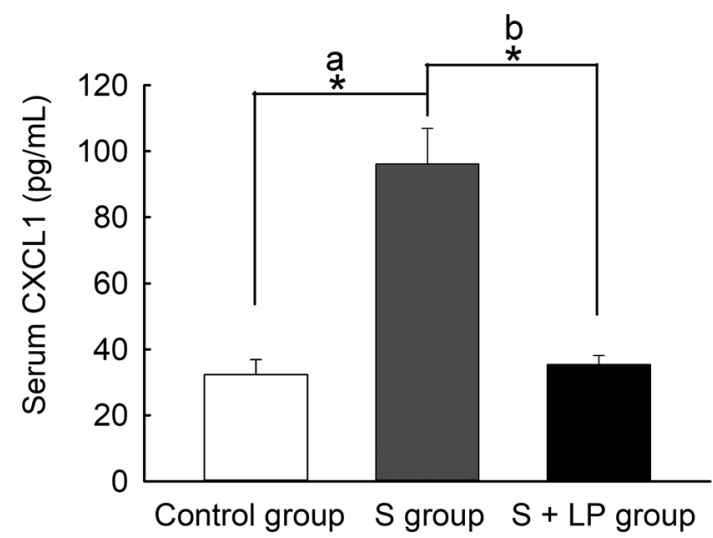

Figure 5. Concentration of serum $\mathrm{CXCL1}(\mathrm{pg} / \mathrm{mL})$. Control group $(n=8)$ : mice administered $0.85 \%$ saline; $S$ group $(n=8)$ : mice administered S. typhimurium $3 \times 10^{9} \mathrm{CFU} / \mathrm{mL} ; \mathrm{S}+\mathrm{LP}$ group $(\mathrm{n}=8)$ : mice administered L. plantarum $B 71 \times 10^{8} \mathrm{CFU} / \mathrm{mL}$ and $S$. typhimurium $3 \times 10^{9} \mathrm{CFU} / \mathrm{mL} .{ }^{*} P<0.05$

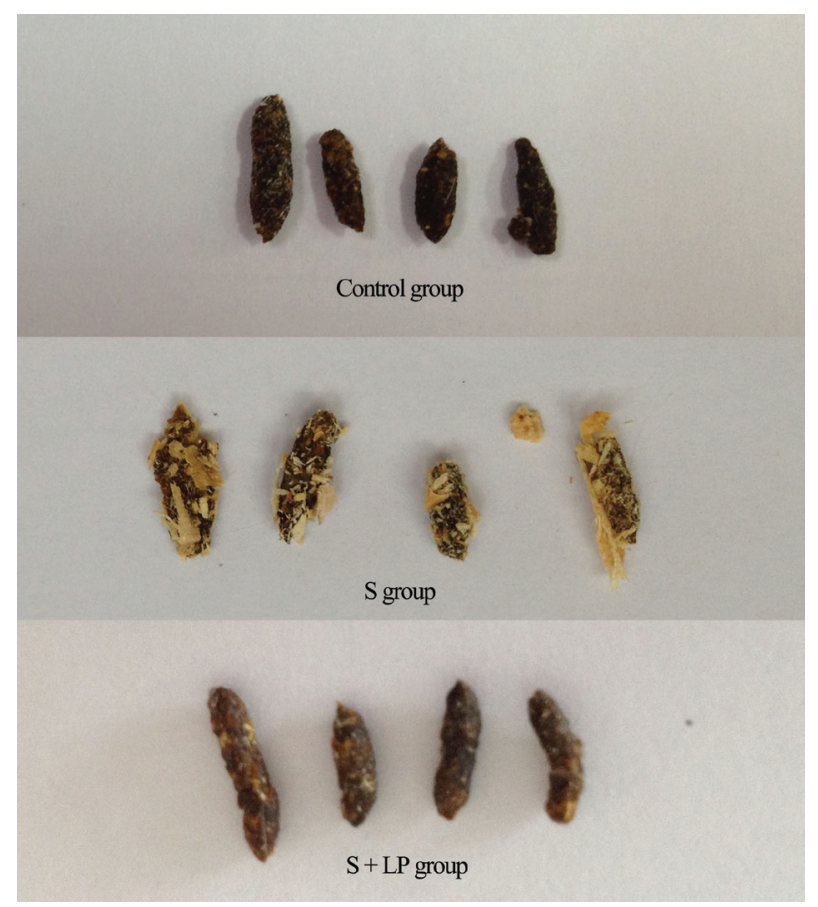

Figure 6. Fecal characteristics of mice in all groups $(n=24)$. Control group $(n=8)$ : mice administered $0.85 \%$ saline; $S$ group $(n=8)$ : mice administered S. typhimurium $3 \times 10^{9} \mathrm{CFU} / \mathrm{mL} ; \mathrm{S}+\mathrm{LP}$ group $(\mathrm{n}=8)$ : mice fed with L. plantarum $\mathrm{B} 71 \times 10^{8} \mathrm{CFU} / \mathrm{mL}$ and S. typhimurium $3 \times 10^{9} \mathrm{CFU} / \mathrm{mL}$.

S + LP group were rod shaped, dark colored, and there was little sawdust around the surface (Figure 6).

\section{Fecal moisture content}

Percentage of mouse fecal moisture content (\%FMC) from all groups are presented in Figure 7. The \%FMC from mice in 


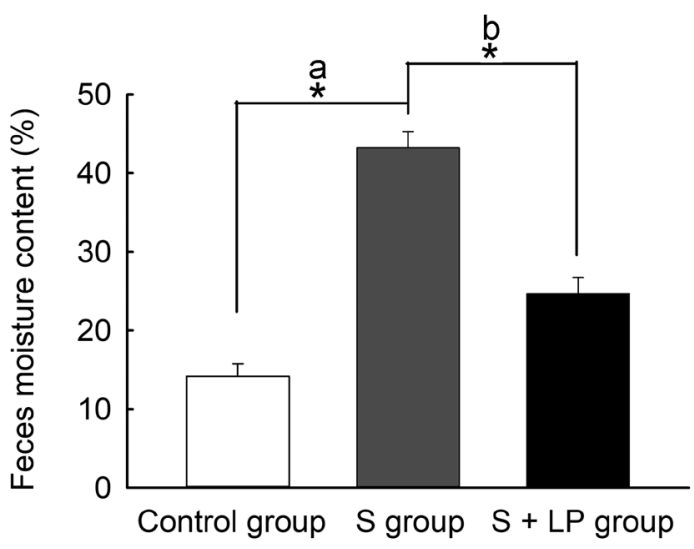

Figure 7. Percentage of feces moisture content (\%FMC) in all groups (mean $\pm S D$ ). Control group $(n=8)$ : mice administered $0.85 \%$ saline; $S$ group ( $\mathrm{n}=8$ ): mice administered S. typhimurium $3 \times 10^{9} \mathrm{CFU} / \mathrm{mL} ; \mathrm{S}+\mathrm{LP}$ group $(\mathrm{n}=8)$ : mice administered L. plantarum $\mathrm{B} 71 \times 10^{8} \mathrm{CFU} / \mathrm{mL}$ and S. Typhimurium $3 \times 10^{9} \mathrm{CFU} / \mathrm{mL}$. ${ }^{*} P<0.05$

the S group (43.24 $\pm 2.05 \%)$ was significantly greater than the $\mathrm{FMC} \%$ from mice in the control group $(14.19 \pm 1.57 \%)$ and mice in the S + LP group $(24.65 \pm 2.08 \%)$.

\section{Discussion}

The present study demonstrates that $S$. typhimurium infection is associated with diarrhea in mice and found protective effects of $L$. plantarum $\mathrm{B} 7$ treatment.

In the present experiments, all mice underwent pretreatment with streptomycin $5 \mathrm{mg} / \mathrm{mL}$ drinking water for 3 days. Pretreatment with streptomycin is considered an effective method when attempting to induce $S$. typhimurium infection, because the treatment results in a decrease in native flora in the GI tract of mice causing higher susceptibility to S. typhimurium infection [22] Mice without streptomycin pretreatment did not develop diarrhea, nor does the pretreatment alone as we found in the present study (results not shown).

The body weight of each mouse was measured every day and no significant differences were found between the treatment and control groups (results not shown). However, the body weight of mice in the control group tended to increase. By contrast, after mice were infected with $S$. typhimurium in both $\mathrm{S}$ and $\mathrm{S}+\mathrm{LP}$ groups, body weight tended to decrease. However, the differences were not significant. Nevertheless, mice in the $\mathrm{S}$ group showed reduced activity and had ruffled fur. It is possible that the infection with $S$. typhimurium could have caused the reduced activity and appetite.

In the study in vitro, we found that $L$. plantarum B7 inhibits growth of $S$. typhimurium as seen by the clear zone around the spot. L. plantarum $\mathrm{B} 7$ is a probiotic with antagonist activity properties against pathogenic bacteria. Our findings are consistent with previous studies [23-25] showing that $L$. plantarum $\mathrm{B} 7$ produces effects against pathogen infections by various mechanisms. L. plantarum $\mathrm{B} 7$ can reduce or inhibit pathogen growth by producing antimicrobial or inhibitory substances such as organic acids, hydrogen peroxide, 3-hydroxypropionaldehyde, diacetyl, and bacteriocin [26], which have adverse effects on other bacteria and pathogens. These substances can kill, reduce, or inhibit the growth of pathogens directly [27]. Moreover, organic acid production from L. plantarum $\mathrm{B} 7$ can modulate and change the $\mathrm{pH}$ environment, thus increasing acidity that can either decrease or inhibit survival rates and growth of pathogens.

In vivo, we found antipathogenic bacterial properties of L. plantarum B7 in our mouse model of S. typhimurium-associated gastroenteritis and diarrhoea. We found a decrease in S. typhimurium concentration in feces as was found by stool culture and colony counts. Aside from antimicrobial substances that inhibit the growth of S. typhimurium, L. plantarum B7 may reduce and inhibit the infection by these pathogenic bacteria by competitive exclusion. Our present findings are consistent with those of Shahlaa et al. who showed that administration of L. plantarum $10^{9} \mathrm{CFU} / \mathrm{mL}$ after infection of mice with $0.5 \times 10^{5} \mathrm{CFU} / \mathrm{mL}$ of $S$. typhimurium can attenuate necrosis, degenerative changes, and inflammatory cell infiltration. Treatment or even pretreatment with $L$. plantarum can improve the histopathological outcome [28]. Hiroki et al. also demonstrated that mice administered with heat-killed L. plantarum b240 for 3 weeks were protected from infection with $S$. typhimurium. L. plantarum b240 was considered to inhibit the binding and invasion of $S$. typhimurium into epithelial cells and decreased the translocation of S. typhimurium into other organs (Payer's patches, mesenteric lymph nodes, spleen, and liver) [29]. Chompoonut et al. suggested that L. plantarum B7 plays a preventive role against pathogenic bacterial infection by demonstrating it inhibited growth of Helicobacter pylori in vitro. Moreover, they found $L$. plantarum $\mathrm{B} 7$ attenuated the histopathology of gastric inflammation induced by $H$. pylori [30]. L. plantarum B7 are a type of so called "friendly bacteria" for human hosts and can live and survive in the human GI tract. Offering many supposed benefits for human hosts, probiotics can improve and modulate the commensal bacterial balance in the GI tract and protect humans from pathogenic infections [31].

We found proinflammatory cytokines (TNF- $\alpha$, IL- 6 , and CXCL1) were significantly decreased in the $\mathrm{S}+\mathrm{LP}$ group. This is consistent with previous findings that $L$. plantarum reduces levels of proinflammatory cytokines [32-35] Panpetch et al. found that $L$. plantarum B7 can reduce TNF- $\alpha$ in vitro [36]. Dick et al. found that $L$. plantarum 423 and E. mundtii ST4SA 
may alleviate physical symptoms of infection with $S$. typhimurium. L. plantarum 423 alone was more effective than $E$. mundtii ST4SA or a combination of both bacterial types [37].

\section{Conclusions}

L. plantarum B7 is effective against infection by S. typhimurium by inhibiting its growth, decreasing serum levels of inflammatory cytokines (TNF- $\alpha$, IL- 6 , and CXCL1), and improving fecal moisture content and characteristics, thus alleviating diarrhea in mice infected with $S$. typhimurium. Further research is required to clarify other protective mechanisms of $L$. plantarum B7. These findings may be applicable to further studies of the prevention and treatment of Salmonellaassociated infections.

Author contributions. SW and DW contributed substantially to the conception and design of the present study. ST acquired the data and SW analyzed and interpreted the data. DW contributed substantially to drafting the manuscript, and SW and ST critically contributed to its revision. All authors approved the final version submitted, and take the responsibility for the statements made in the published article.

Acknowledgments. This study was supported by the 90th Anniversary Fund of Chulalongkorn University (Ratchada phiseksomphot Endowment Fund) and The Grant of Ratchadaphiseksomphot, Faculty of Medicine, Chulalongkorn University, Bangkok, Thailand.

Conflict of interest statement. The authors have each completed and submitted an International Committee of Medical Journal Editors Uniform Disclosure Form for Potential Conflicts of Interest. None of the authors disclose any conflict of interest.

\section{References}

[1] McClelland M, Wilson RK. Comparison of sample sequences of the Salmonella typhi genome to the sequence of the complete Escherichia coli K-12 genome. Infect Immun. 1998; 66:4305-12.

[2] Hapfelmeier S, Hardt WD. A mouse model for S. typhimuriuminduced enterocolitis. Trends Microbiol. 2005; 13:497-503.

[3] Coburn B, Grassl GA, Finlay BB. Salmonella, the host and disease: a brief review. Immunol Cell Biol. 2007; 85:112-8.

[4] Guandalini S. Probiotics for prevention and treatment of diarrhea. J Clin Gastroenterol. 2011; 45(Suppl):S149-53.

[5] Williams NT. Probiotics. Am J Health Syst Pharm. 2010; 67:449-58.

[6] de Vrese M, Marteau PR. Probiotics and prebiotics: effects on diarrhea. J Nutr. 2007; 137(Suppl 3):S803-11.
[7] Yan F, Polk, DB. Commensal bacteria in the gut: learning who our friends are. Curr Opin Gastroenterol. 2004; 20:565-71.

[8] Niedzielin K, Kordecki H, Birkenfeld B. A controlled, double-blind, randomized study on the efficacy of Lactobacillus plantarum 299V in patients with irritable bowel syndrome. Eur J Gastroenterol Hepatol. 2001; 13:1143-7.

[9] Sullivan A, Nord CE. Probiotics and gastrointestinal diseases. J Intern Med. 2005; 257:78-92.

[10] Yan F, Polk DB. Probiotics as functional food in the treatment of diarrhea. Curr Opin Clin Nutr Metab Care. 2006; 9:717-21.

[11] Teanpaisan R, Piwat S, Dahlén G. Inhibitory effect of oral Lactobacillus against oral pathogens. Lett Appl Microbiol. 2011; 53:452-9.

[12] Dhanani AS, Bagchi T. Lactobacillus plantarum CS24.2 prevents Escherichia coli adhesion to HT-29 cells and also down-regulates enteropathogen-induced tumor necrosis factor-a and interleukin-8 expression. Microbiol Immunol. 2013; 57:309-15.

[13] Duary RK, Bhausaheb MA, Batish VK, Grover S. Anti-inflammatory and immunomodulatory efficacy of indigenous probiotic Lactobacillus plantarum Lp91 in colitis mouse model. Mol Biol Rep. 2012; 39:4765-75.

[14] Noguchi S, Hattori M, Sugiyama H, Hanaoka A, Okada S, Yoshida T. Lactobacillus plantarum NRIC1832 enhances IL-10 production from $\mathrm{CD}^{+}$T cells in vitro. Biosci Biotechnol Biochem. 2012; 76:1925-31.

[15] Anderson RC, Cookson AL, McNabb WC, Kelly WJ, Roy NC. Lactobacillus plantarum DSM 2648 is a potential probiotic that enhances intestinal barrier function. FEMS Microbiol Lett. 2010; 309:184-92.

[16] Frias J, Song YS, Martinez-Villaluenga C, González de Mejia E, Vidal-Valverde C. Immunoreactivity and amino acid content of fermented soybean products. J Agric Food Chem. 2008; 56:99-105.

[17] Spinler JK, Taweechotipatr M, Rognerud CL, Ou CN, Tumwasorn S, Versalovic J. Human-derived probiotic Lactobacillus reuteri demonstrate antimicrobial activities targeting diverse enteric bacterial pathogens. Anaerobe. 2008; 14:166-71.

[18] Panpetch W. Detection of Lactobacillus in the stomach of dyspeptic patients and its role in the suppression of TNF production in vitro [MSc Thesis]. Bangkok, Thailand: Chulalongkorn Univ., 2008.

[19] Barthe M, Hapfelmeier S, Quintanilla-Martínez L, Kremer M, Rohde M, Hogardt M, et al. Pretreatment of mice with streptomycin provides a Salmonella enterica serovar Typhimurium colitis model that allows analysis of both pathogen and host. Infect Immun. 2003; 71:2839-58.

[20] Bouraoui M, Richard P, Fichtali J. A review of moisture content determination in foods using microwave oven drying. Food Research International. 1993; 26:49-51.

[21] Nishimuta M, Inoue N, Kodama N, Moriknni E, Yoshioka YH, Matsuzaki N, et al. Moisture and mineral content of human feces-high fecal moisture is associated with increased sodium and decreased potassium content. J Nutr Sci Vitaminol. 2006; 52:121-6.

[22] Bohnhoff M, Drake BL, Miller CP. Effect of streptomycin on susceptibility of intestinal tract to experimental Salmonella infection. Proc Soc Exp Biol Med. 1954; 86:132-7.

[23] Abdel-Daim A, Hassouna N, Hafez M, Ashor MS, Aboulwafa MM Antagonistic activity of Lactobacillus isolates against Salmonella typhi in vitro. Biomed Res Int. 2013; 2013:680605. doi: 10.1155/2013/680605

[24] Chiu HH, Tsai CC, Hsih HY, Tsen HY. Screening from pickled vegetables the potential probiotic strains of lactic acid bacteria able to inhibit the Salmonella invasion in mice. J Appl Microbiol. 2008; 104:605-12. 


\section{Allli ASIAN BIOMEDICINE}

[25] Das JK, Mishra D, Ray P, Tripathy P, Beuria TK, Singh N, Suar M. In vitro evaluation of anti-infective activity of a Lactobacillus plantarum strain against Salmonella enterica serovar Enteritidis. Gut Pathog. 2013; 5:11. doi: 10.1186/1757-4749-5-11

[26] Zhu X, Zhao Y, Sun Y, Gu Q. Purification and characterisation of plantaricin ZJ008, a novel bacteriocin against Staphylococcus spp. from Lactobacillus plantarum ZJ008. Food Chem. 2014; 165:216-23.

[27] Hasslöf P, Hedberg M, Twetman S, Stecksén-Blicks C. Growth inhibition of oral mutans streptococci and candida by commercial probiotic lactobacilli - an in vitro study. BMC Oral Health. 2010; 10:18. doi: 10.1186/1472-6831-10-18

[28] Shahlaa MS, Zahraa KZ. Protective effect of Lactobacillus plantarum against Salmonella typhimurium in mice. J Fac Med Baghdad. 2010; 52:475-9.

[29] Ishikawa H, Kutsukake E, Fukui T, Sato I, Shirai T, Kurihara T, et al. Oral administration of heat-killed Lactobacillus plantarum strain b240 protected mice against Salmonella enterica serovar Typhimurium. Biosci Biotechnol Biochem. 2010; 74:1338-42.

[30] Sunanliganon C, Thong-Ngam D, Tumwasorn S, Klaikeaw N. Lactobacillus plantarum B7 inhibits Helicobacter pylori growth and attenuates gastric inflammation. World J Gastroenterol. 2012; 18:2472-80.

[31] O'Toole PW, Cooney JC. Probiotic bacteria influence the composition and function of the intestinal microbiota. Interdiscip Perspect Infect Dis. 2008; 2008:175285. doi: 10.1155/2008/175285
[32] Bäuerl C, Llopis M, Antolín M, Monedero V, Mata M, Zúñiga M, et al. Lactobacillus paracasei and Lactobacillus plantarum strains downregulate proinflammatory genes in an ex vivo system of cultured human colonic mucosa. Genes Nutr. 2013; 8:165-80.

[33] Borthakur A, Anbazhagan AN, Kumar A, Raheja G, Singh V, Ramaswamy K, Dudeja PK. The probiotic Lactobacillus plantarum counteracts TNF- $\alpha$-induced downregulation of SMCT1 expression and function. Am J Physiol Gastrointest Liver Physiol. 2010; 299:G928-34.

[34] Kim H, Jung BJ, Jung JH, Kim JY, Chung SK, Chung DK. Lactobacillus plantarum lipoteichoic acid alleviates TNF- $\alpha$-induced inflammation in the HT-29 intestinal epithelial cell line. Mol Cells. 2012; 33:479-86.

[35] Puertollano E, Puertollano MA, Cruz-Chamorro L, Álvarez de Cienfuegos G, Ruiz-Bravo A, de Pablo MA. Orally administered Lactobacillus plantarum reduces pro-inflammatory interleukin secretion in sera from Listeria monocytogenes infected mice. Br J Nutr. 2008; 99:819-25.

[36] Panpetch W, Thiraworawong T, Tumwasorn S. Human gastric biopsy-derived lactobacilli suppress Helicobacter pylori-induced interleukin-8 production from gastric epithelial cells in vitro. Int J Infereron Cytokine Mediator Res. 2011; 3:43-9.

[37] Dicks LM, ten Doeschate K. Enterococcus mundtii ST4SA and Lactobacillus plantarum 423 alleviated symptoms of Salmonella infection, as determined in Wistar rats challenged with Salmonella enterica serovar Typhimurium. Curr Microbiol. 2010; 61:184-9. 